\title{
Response of Different Varietal Evaluation of Dahlia (Dahlia variabilis L.) Under Prayagraj Agro-climatic Conditions
}

\author{
T. Mounika* and S.S. Saravanan \\ Department of Horticulture, Naini Agricultural Institute (NAI), \\ Sam Higginbottom University of Agriculture, Technology and Sciences, \\ Prayagraj - 211007, India \\ *Corresponding author
}

An experiment entitled "Response of different varietal evaluation of Dahlia under Prayagraj Agro-climatic conditions" was carried out in Horticulture Research Farm,

\section{Keywords}

Varietal evaluation, Dahlia, Cheroky Beauty, Glory of India

Article Info

Accepted:

20 July 2019

Available Online:

10 August 2019
SHUATS, NAI, Prayagraj during 2018-2019.The experiment was laid out in simple Randomized Block Design with three replications and fifteen treatments with a view to find out the overall evaluation of different hybrid varieties of Dahlia viz Duet, Fire and Ice, Ice Cube, Hamari Gold, Orange Turmoil, Yellow Ball, Yellow White Ball, Glory of India, Kenya Yellow, Kenya Scarlet Purple, Cheroky Beauty, Perfect Orange, Axford Gold, Prime Minister, Scarlet Striped Pink, on the basis of different growth and yield parameters. Maximum plant height was found in hybrid 'Cheroky Beauty' $(97.38 \mathrm{~cm})$. Maximum number of compound leaves is found in 'Glory of India' (12-15). Minimum number of days taken for flower bud initiation from planting (56.86 days) was found in hybrid Duet. Maximum diameter of fully opened flower $(18.13 \mathrm{~cm})$ was found in hybrid Yellow Ball. Maximum weight of single flower (24.46 g) was found in hybrid Ice Cube. Maximum flower duration (63.87 days) was found in Kenya Scarlet Purple. Maximum number of flowers per plant (25.36) was found in hybrid Scarlet Striped Pink.

\section{Introduction}

Dahlia (Dahlia variabilis L.) is one of the most popular tuberous rooted perennial, herbaceous flowering plants, valued for their gorgeous attractive spectacular flowers. This plant is being grown in many parts of the world for its beautiful ornamental blooms of varying shades of colors for the beautification of gardens, for cut flowers and as a loose flower. It belongs to the family Asteraceae. Dahlia originated in Mexico, which received its name by Cavanilles in the year 1791, to commemorate the work of a Swedish Botanist Dr. Andreas Dahl, a pupil of Linneaus (Smith, 1971). Dahlia was introduced to India as early as 1857 under the auspices of the AgriHorticultural Society of India (formerly, Royal Agri - Horticultural Society of India). The height of dahlia plants varies from 30 to $180 \mathrm{~cm}$ depending upon the cultivar. Dahlia flower consists of a certain number of outer ray florets in which the male organs are modified in to a strap shaped petal, arranged 
round a central disk of bisexual florets. Dwarf growing types are suitable for flower beds and borders (pure or mixed borders) whereas, large flowering dahlia for pot. Cut flowers of pompon and miniature types stay fresh in flower vases for many days and better to make moderately good garlands and to use as individual loose flower. To obtain more flowers / plant, stress should be given on the number of branches / plant during selection of cultivars and strains. Plant height and number of leaves also showed a slight positive effect on the number of flowers (Suman et al., 1991). Dahlia hybridization has so for been done by the commercial dahlia growers and armatures in different parts of the world, mostly in America, New Zealand, Holland and England. In India Swami Vinyanand, a monk of the Ramakrishna order has done a good deal of breeding work using handpollination technique. Some of their most popular hybrids are Bhikkus mother, Bhikkus vivek and Swami Lakeswarnanda. Certain species of dahlias have medicinal and nutritional uses. Tubers of this plant contain significant amount of insulin and fructose and small quantities of medicinally active compounds such as pythin and benzoic acid.

\section{Materials and Methods}

A field experiment entitled " Response of different varietal evaluation of Dahlia (Dahlia variabilis L.) under Prayagraj Agro-climatic conditions" was conducted at Horticultural Research Farm, Department of Horticulture, NAI, Sam Higginbottom University of Agriculture, Technology and Sciences. The experiment was conducted during winter season of the year 2018-19 in crop Research plot of Department of Horticulture, Naini Agricultural Institute (NAI) Sam Higginbottom University of Agricultural Technology and Sciences, Prayagraj. The area is situated on the South of Prayagraj on the right bank of Yamuna at Rewa road at a distance of about $6 \mathrm{~km}$ from Prayagraj city. It is situated at $25^{\circ} .85^{\prime} \mathrm{N}$ latitude and $81^{\circ} .57^{\prime} \mathrm{E}$ longitudes on elevation of 98 meters from the sea level. The area of Allahabad district comes under subtropical belt in the South east of Uttar Pradesh, which experience extremely hot summer and fairly cold winter. The maximum temperature of the location reaches up to $46^{\circ} \mathrm{C}-48^{\circ} \mathrm{C}$ and seldom falls as low as $2^{\circ} \mathrm{C}-5^{\circ} \mathrm{C}$. The relative humidity ranges between 20 to 94 percent. The varieties under study were also found to have a great variation in flower colour from orange (varieties 'Cheroky Beauty', 'Axford Gold', 'Hamari Gold', 'Orange Turmoil', 'Glory of India', 'Perfect Orange'). Varieties 'Ice Cube', 'Yellow Ball', 'Yellow White Ball', 'Kenya Yellow' showed yellowish and whitish yellow flowers, while 'Duet', 'Fire \& Ice' reddish and whitish red flowers and 'Scarlet striped Pink' \& 'Prime Minister' showed pink flowers, 'Kenya scarlet Purple 'showed purple flowers.

\section{Results and Discussion}

The result of the present study as well as relevant discussion has been presented under following sub heads:

The maximum plant height was found in the hybrid Cheroky Beauty $(97.38 \mathrm{~cm})$ followed by perfect orange $(96.84 \mathrm{~cm})$ where as minimum was found in hybrid Ice Cube $(76.63 \mathrm{~cm})$. Maximum stem girth was found in hybrid Scarlet Striped Pink $(1.21 \mathrm{~cm})$ whereas, minimum stem girth was found in hybrid Fire and Ice $(0.99 \mathrm{~cm})$. Maximum number of leaflets per compound leaf (12-15) was found in Glory of India, whereas the minimum number of leaflets was found in Duet, Fire and Ice, Orange turmoil, Axford gold, Prime minister (3-5). The maximum leaf area $(51.37 \mathrm{~cm})$ was found in Orange turmoil, whereas minimum was found in Glory of India $(25.88 \mathrm{~cm})$. The minimum number of 
days required for bud emergence from planting (56.86 days) was found in hybrid Duet and maximum number of days required for flower bud initiation is (60.33 days). Maximum diameter of fully opened flower $(18.13 \mathrm{~cm})$ was found in hybrid Yellow ball whereas, minimum diameter of fully opened flower $(10.8 \mathrm{~cm})$ was found in Fire and Ice. Maximum weight of single flower (24.46 g) was found in Ice cube whereas, minimum weight of single flower is $(16.43 \mathrm{~g})$ was found in Orange turmoil. Maximum number of flowers per plant (25.36) was found in Scarlet stripe pink followed by Kenya yellow, whereas minimum number of flowers per plant was recorded in Yellow ball (14.36). Maximum number of ray florets per flower
(151.76) was found in Cheroky beauty, whereas minimum number of ray florets was found in (17.23) Scarlet striped pink. Maximum Vase life (61.41 days) was found in Fire and Ice, whereas minimum vase life was found in (2.97 days) Prime minister. Maximum flower stalk length was found in $(21.46 \mathrm{~cm})$ Yellow white ball, whereas minimum was found in $(6.23 \mathrm{~cm})$ Kenya yellow. Maximum duration of flowers (63.87 days) was found in Kenya scarlet purple, whereas minimum flower duration was found in Yellow white ball (32.80 days). Maximum longevity of flowers was found in Kenya yellow (13.43 days), whereas minimum longevity was found in (4.47 days).

Table.1 Effect of different varieties of Dahlia on growth parameters

\begin{tabular}{|c|c|c|c|c|c|c|c|}
\hline \multirow[t]{2}{*}{ S. No. } & \multirow[t]{2}{*}{ Varieties } & \multicolumn{3}{|c|}{ Plant Height (cm) } & \multicolumn{3}{|c|}{ Leaf Area $\left(\mathrm{cm}^{2}\right)$} \\
\hline & & $\begin{array}{c}30 \\
\text { DAT }\end{array}$ & $60 \mathrm{DAT}$ & $\begin{array}{c}90 \\
\text { DAT }\end{array}$ & $\begin{array}{c}30 \\
\text { DAT }\end{array}$ & $\begin{array}{c}60 \\
\text { DAT }\end{array}$ & $\begin{array}{l}90 \\
\text { DAT }\end{array}$ \\
\hline 1 & Duet & 17.19 & 51.93 & 80.09 & 29.11 & 33.52 & 39.25 \\
\hline 2 & Fire \& Ice & 18.32 & 51.98 & 82.07 & 21.10 & 21.07 & 29.43 \\
\hline 3 & Ice Cube & 20.49 & 60.48 & 76.63 & 38.09 & 42.27 & 48.04 \\
\hline 4 & Hamari Gold & 19.60 & 59.39 & 86.57 & 26.92 & 29.38 & 36.22 \\
\hline 5 & Orange Turmoil & 20.02 & 64.58 & 83.80 & 36.00 & 39.08 & 51.37 \\
\hline 6 & Yellow Ball & 16.66 & 57.76 & 88.05 & 19.01 & 22.35 & 27.09 \\
\hline 7 & Yellow White Ball & 19.15 & 66.91 & 78.11 & 34.23 & 41.10 & 42.11 \\
\hline 8 & Glory Of India & 20.23 & 62.55 & 94.11 & 16.50 & 18.70 & 25.88 \\
\hline 9 & Kenya Yellow & 19.65 & 64.69 & 83.08 & 38.37 & 41.00 & 42.05 \\
\hline 10 & Kenya Scarlet Purple & 15.12 & 70.13 & 96.41 & 19.09 & 22.25 & 33.15 \\
\hline 11 & Cheroky Beauty & 19.51 & 63.93 & 97.38 & 31.52 & 40.57 & 50.95 \\
\hline 12 & Perfect Orange & 18.86 & 73.01 & 96.84 & 22.08 & 25.63 & 35.91 \\
\hline 13 & Axford Gold & 20.21 & 67.89 & 81.59 & 36.16 & 40.32 & 49.48 \\
\hline 14 & Prime Minister & 21.28 & 69.58 & 93.80 & 19.20 & 28.30 & 33.03 \\
\hline 15 & Scarlet Striped Pink & 20.01 & 67.26 & 93.13 & 23.26 & 40.53 & 47.97 \\
\hline & F Table (5\%) & $\mathrm{S}$ & $\mathrm{S}$ & $\mathrm{S}$ & $\mathrm{S}$ & $\mathrm{S}$ & $\mathrm{S}$ \\
\hline & SE $\mathbf{m} \pm$ & 0.5647 & 5.9017 & 4.1607 & 0.0051 & 0.0159 & 0.02821 \\
\hline & C.D. (5\%) & 1.6358 & 17.0966 & 12.0530 & 0.0151 & 0.046 & 0.08171 \\
\hline
\end{tabular}


Table.2 Effect of different varieties of Dahlia on growth parameters

\begin{tabular}{|c|c|c|c|c|c|}
\hline \multirow[t]{2}{*}{ S.NO. } & \multirow[t]{2}{*}{ VARIETIES } & \multicolumn{3}{|c|}{ Stem girth $(\mathbf{c m})$} & \multirow{2}{*}{$\begin{array}{l}\text { Number of leaf } \\
\text { lets/ compound } \\
\text { leaf }\end{array}$} \\
\hline & & $30 \mathrm{DAT}$ & $60 \mathrm{DAT}$ & 90 DAT & \\
\hline 1 & Duet & 0.32 & 0.71 & 1.02 & $3-5$ \\
\hline 2 & Fire \& Ice & 0.32 & 0.72 & 0.99 & $3-5$ \\
\hline 3 & Ice Cube & 0.34 & 0.8 & 1.11 & $3-6$ \\
\hline 4 & Hamari Gold & 0.32 & 0.72 & 1.03 & 3-8 \\
\hline 5 & Orange Turmoil & 0.36 & 0.82 & 1.13 & $3-5$ \\
\hline 6 & Yellow Ball & 0.31 & 0.73 & 1.04 & $3-7$ \\
\hline 7 & Yellow White Ball & 0.37 & 0.85 & 1.15 & $3-8$ \\
\hline 8 & Glory Of India & 0.32 & 0.76 & 1.05 & $12-15$ \\
\hline 9 & Kenya Yellow & 0.35 & 0.85 & 1.17 & $3-9$ \\
\hline 10 & Kenya Scarlet Purple & 0.31 & 0.76 & 1.08 & 3-8 \\
\hline 11 & Cheroky Beauty & 0.34 & 0.84 & 1.20 & $3-9$ \\
\hline 12 & Perfect Orange & 0.31 & 0.74 & 1.10 & $3-6$ \\
\hline 13 & Axford Gold & 0.35 & 0.84 & 1.15 & $3-5$ \\
\hline 14 & Prime Minister & 0.32 & 0.74 & 1.11 & $3-5$ \\
\hline \multirow[t]{4}{*}{15} & Scarlet Striped Pink & 0.35 & 0.86 & 1.21 & $3-7$ \\
\hline & F Table (5\%) & $S$ & $\mathrm{~S}$ & S & NIL \\
\hline & $\mathbf{S E} \mathbf{m} \pm$ & 0.3139 & 0.4178 & 0.5367 & NIL \\
\hline & $\mathrm{CD}(0.05)$ & 0.9094 & 1.2103 & 1.5548 & NIL \\
\hline
\end{tabular}

Fig.1 Effect of different varieties of Dahlia on growth parameters

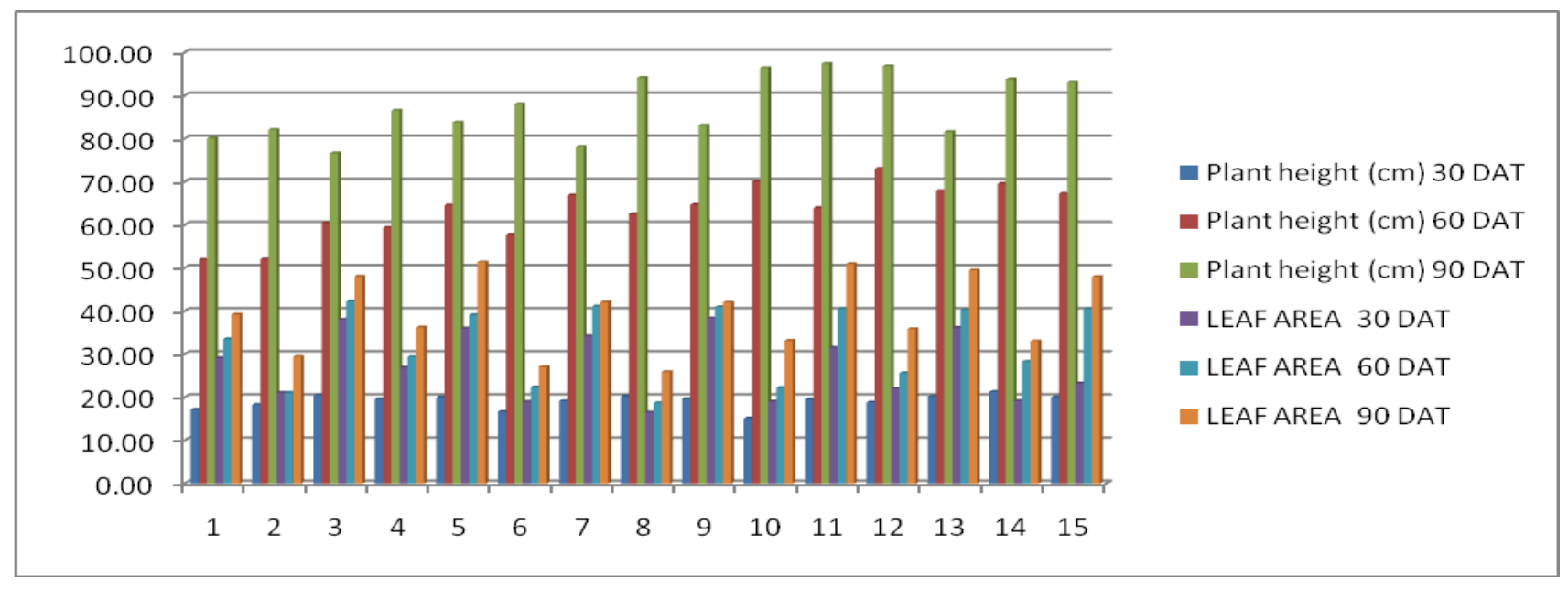


Table.3 Effect of different varieties of Dahlia on flower parameters

\begin{tabular}{|c|c|c|c|c|c|}
\hline Varieties & $\begin{array}{l}\text { No. of ray } \\
\text { floret per } \\
\text { flower }\end{array}$ & $\begin{array}{c}\text { Vase life of } \\
\text { flower } \\
\text { (days) }\end{array}$ & $\begin{array}{c}\text { Flower } \\
\text { stalk } \\
\text { length } \\
\text { (cm) }\end{array}$ & $\begin{array}{c}\text { Duration of } \\
\text { flower } \\
\text { (days) }\end{array}$ & $\begin{array}{c}\text { Longevity } \\
\text { (days) }\end{array}$ \\
\hline Duet & 126.63 & 6.40 & 13.06 & 35.23 & 12.44 \\
\hline Fire \& Ice & 93.86 & 6.41 & 8.3 & 49.33 & 12.43 \\
\hline Ice Cube & 114.63 & 5.40 & 6.66 & 39.57 & 4.47 \\
\hline Hamari Gold & 123.33 & 4.60 & 11.86 & 52.00 & 9.23 \\
\hline Orange Turmoil & 112.96 & 5.40 & 12.96 & 50.83 & 10.53 \\
\hline Yellow Ball & 115.06 & 6.20 & 9.53 & 45.77 & 9.30 \\
\hline Yellow White Ball & 111.93 & 5.13 & 21.46 & 32.80 & 12.37 \\
\hline Glory Of India & 86.96 & 6.00 & 12.23 & 37.47 & 10.33 \\
\hline Kenya Yellow & 100.96 & 4.27 & 6.23 & 58.80 & 13.43 \\
\hline Kenya Scarlet Purple & 116.36 & 6.20 & 15.2 & 63.87 & 11.33 \\
\hline Cheroky Beauty & 151.76 & 5.33 & 12.33 & 43.47 & 6.23 \\
\hline Perfect Orange & 143.16 & 4.53 & 12.2 & 32.87 & 9.50 \\
\hline Axford Gold & 107.26 & 5.37 & 18.96 & 41.47 & 7.40 \\
\hline Prime Minister & 125.63 & 2.97 & 16.26 & 41.73 & 11.37 \\
\hline Scarlet Striped Pink & 17.23 & 3.47 & 17.23 & 45.67 & 7.5 \\
\hline F Table (5\%) & $\mathrm{S}$ & $\mathrm{S}$ & S & S & $\mathrm{S}$ \\
\hline S. EM \pm & 1.7065 & 0.4054 & 1.1598 & 0.9773 & 0.1678 \\
\hline $\mathrm{CD}(0.05)$ & 4.9435 & 1.1743 & 3.3598 & 2.8312 & 0.4862 \\
\hline
\end{tabular}

Fig.2 Effect of different varieties of Dahlia on growth parameters

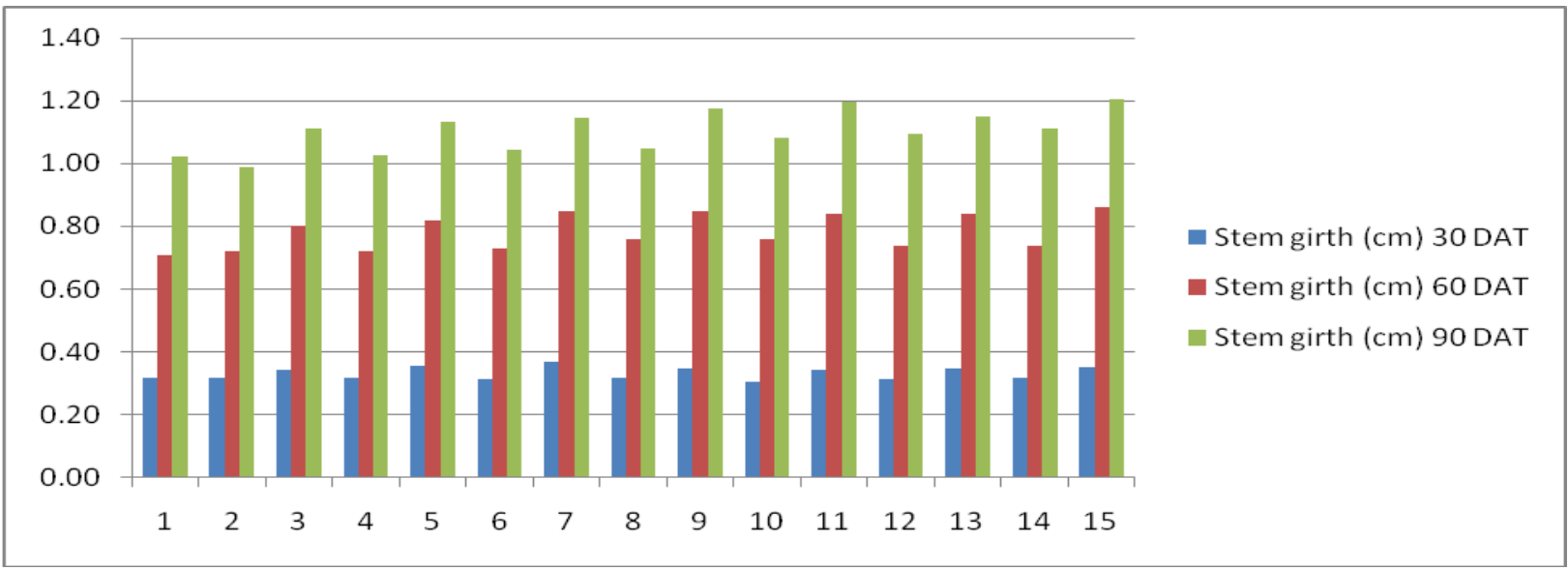


Table.4 Effect of different varieties of Dahlia on flower parameter

\begin{tabular}{|l|c|c|c|c|c|}
\hline \multicolumn{1}{|c|}{ VARIETIES } & $\begin{array}{c}\text { No. of days } \\
\text { taken for flower } \\
\text { bud initiation }\end{array}$ & $\begin{array}{c}\text { Diameter } \\
\text { of flower } \\
\text { (cm) }\end{array}$ & $\begin{array}{c}\text { Individual } \\
\text { flower } \\
\text { weight }(\mathbf{g m})\end{array}$ & $\begin{array}{c}\text { No. of } \\
\text { flower } \\
\text { per plant }\end{array}$ & $\begin{array}{c}\text { No. of days } \\
\text { taken for } \\
\text { flowering }\end{array}$ \\
\hline Duet & 56.86 & 13.43 & 24.02 & 23.46 & 76.90 \\
\hline Fire \& Ice & 56.86 & 10.8 & 16.46 & 18.26 & 83.20 \\
\hline Ice Cube & 45.3 & 11.63 & 22.46 & 14.6 & 79.30 \\
\hline Hamari Gold & 51.06 & 18.1 & 17.36 & 17.46 & 91.53 \\
\hline Orange Turmoil & 47.23 & 11.76 & 16.43 & 19.5 & 86.70 \\
\hline Yellow Ball & 60.33 & 18.13 & 17.66 & 14.36 & 79.77 \\
\hline Yellow White Ball & 58.2 & 10.66 & 20.26 & 22.66 & 86.73 \\
\hline Glory Of India & 52.5 & 12.4 & 20.23 & 28.4 & 94.77 \\
\hline Kenya Yellow & 42.96 & 18.06 & 19.83 & 25.36 & 82.83 \\
\hline Kenya Scarlet Purple & 50.2 & 14.13 & 24.46 & 24.33 & 80.80 \\
\hline Cheroky Beauty & 48.26 & 10.33 & 18.83 & 21.73 & 88.63 \\
\hline Perfect Orange & 53.26 & 15.23 & 23.06 & 19.46 & 85.73 \\
\hline Axford Gold & 46.13 & 11.133 & 19.2 & 22.6 & 78.83 \\
\hline Prime Minister & 56.33 & 14.06 & 22.5 & 18.5 & 74.60 \\
\hline Scarlet Striped Pink & 42.13 & 17.23 & 22.7 & 25.36 & 84.77 \\
\hline F Table (5\%) & $\mathrm{S}$ & $\mathrm{S}$ & $\mathrm{S}$ & $\mathrm{S}$ & $\mathrm{S}$ \\
\hline SE m \pm & 0.2939 & 0.8479 & 1.4516 & 0.3377 & 0.2079 \\
\hline C.D. (5\%) & 0.8513 & 2.4564 & 4.2052 & 0.9784 & 0.6024 \\
\hline
\end{tabular}

Fig.3 Effect of different varieties of Dahlia on flower parameters

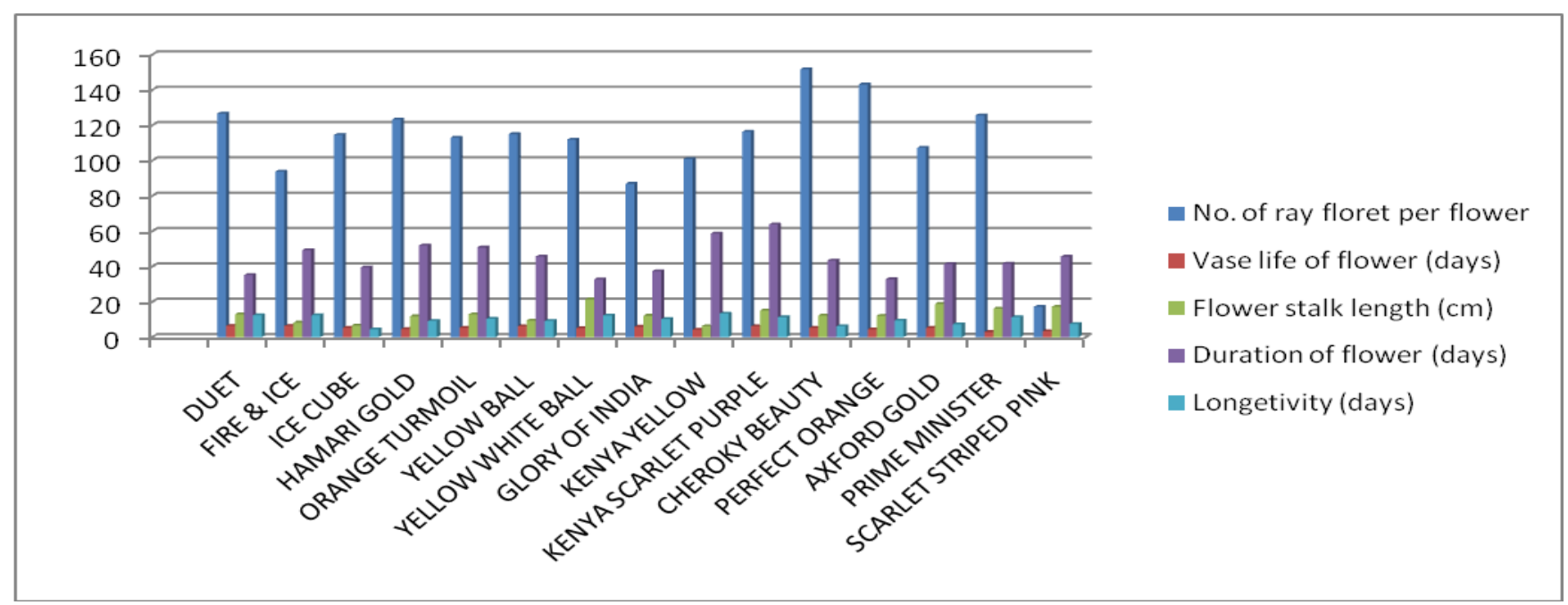


Fig.4 Effect of different varieties of Dahlia on flower parameter

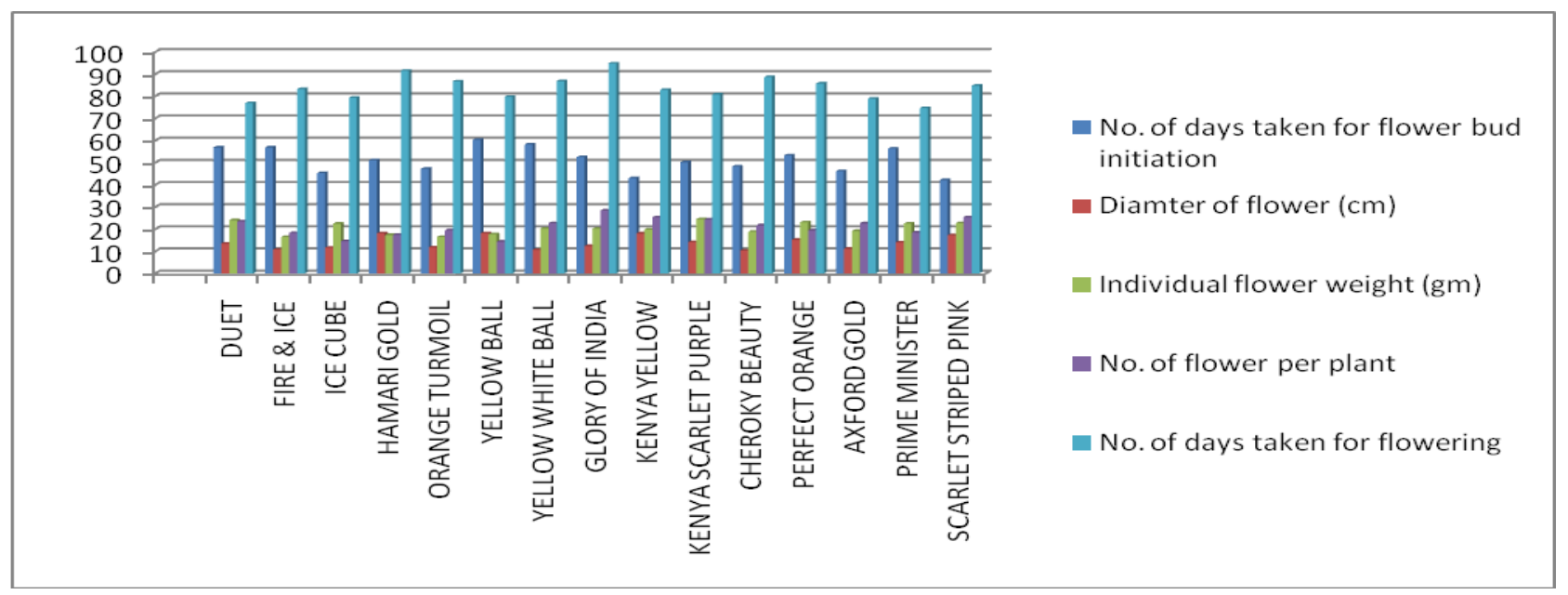

Plant height being a genetically controlled factor, it varied among the genotypes as well as influence of the growing environmental conditions, production technology and cultural practices. Similar variation in plant height due to cultivars was also observed in dahlia by (Syamal and Kumar, 2002), and Vikas et al., (2015), in China aster by (Munikrishnappa, 2013), (Chowdhuri et al., 2015), (Chourasia et al., 2015), in Gladiolus. Plant spread is an important growth factor for flower crops. It helps to utilize the sunlight to maximum extent. Plant spread differed significantly among all the varieties studied which is due to genetic makeup of the cultivars and development of more secondary branches in the cultivars thereby increasing plant spread. Similar results were also reported by Kumar et al., (2009) found in Dahlia. The variation among the varieties in number of branches is due to the genetic difference as most of the characters are governed by genetic make-up of the varieties. Similar results were also reported by Joshi $e t$ al., (1997) found in Dahlia. Leaves are the functional units for photosynthesis, which greatly influence the growth and may be flower yield of any crop. The variation in number of leaves per plant among the varieties is due top variation in the rate of vegetative growth among the genotypes that could be attributed to genetic makeup and could have been further influence by agro climatic condition. Similar results were reported by Dhane and Nimbalkar (2002) in Dahlia. The varieties have shown significant difference with respect to the number of days taken for first flower bud emergence, it is may be due to its better growth and development in terms of maximum number of leaves, branches and plant spread which resulted in higher production accumulation of sugar leading to switching of vegetative phase in reproductive phase. These variations may be attributed to the fact that the performance of varieties may vary with the climatic conditions prevailing in a particular area. Similar results were also reported by Dhane and Nimbalkar (2002), found in Dahlia. The variation among the varieties was mainly because of genetical factors or may be due to cultural operations like disbudding and pinching. Variations expected among the varieties of Dahlia. Similar results were also reported by (Dhane and Nimbalker 2002), (Kumar et al., 2009), and (Mahawer et al., 2010) found in Dahlia. Weight of individual flower is another important character. The variation among the varieties was mainly because of increased flower size and ray florets. Similar results were also reported by (Kanamadi and Patil 2002), (Kumar et al., 
2009) and (Mahawera et al., 2010) found in Dahlia. For garden display, Shelf life or longevity is important factor. The preference of gardener depends on longevity of the varieties, and it may be depends upon the genetic factors or climatic conditions of region. Similar results were also reported by (Dhane and Nimbalker 2002), (Kumar et al., 2009) and (Mahawer et al., 2010) found in Dahlia. Also reported by Negi et al., (1988) in Chrysanthemum. The varieties have shown significant difference with respect to the number of days taken for complete flower opening. These variations may be attributed to the fact that the performance of varieties may vary with the climatic conditions prevailing in Allahabad region. Similar results were also reported by (Dhane and Nimbalkaer 2002) and Vikas et al., (2011) found in Dahlia. The probable reason for variation in number of flowers per plant may be due to the effect of environmental conditions prevailing during field trail. The similar results were observed in Dahlia by (Ahmed and Gul 2002), in China aster by (Munikrishnappa 2013) and (Zosiamliana et al., 2012), in Gladiolus reported by (Pant and Lal 1991). The yield produced flower per plant may be related to increase in plant height, number of branches, better utilization of applying fertilizer and manure in soil, numbers of flower, weight of individual flower, flowering duration. Similar results were also reported by (Kumar et al., 2009) and (Suman et al., 1991) in Dahlia. The yield of flower per hectare is directly related to increase in flower yield per plant, weight of flower, flower size. These variations may be attributed to the fact that the performance of varieties may vary with the climatic conditions prevailing in Allahabad region. Similar results were also reported by (Kumar et al., 2009) and (Suman et al., 1991) in Dahlia.

Based on present investigation, it is concluded that the variety 'Glory of India' was found best in terms of yield 28.4 flowers per plant while 'Kenya Yellow' was found best in terms of vegetative growth and flower parameters followed by variety 'Scarlet Striped Pink' with flower yield of 25.36 flowers per plant. In terms of quality parameters 'Fire and Ice' stood best with the vase life of 6.41 days followed by 'Duet, Yellow Ball, and Kenya Scarlet Striped Pink' $(6.40,6.20,6.20)$ respectively.

\section{References}

Ahmed, M. J., and Gul, S.,(2002). Evaluation of exotic cultivars of dahlia (Dahlia coccinea) under rawalakot conditions. Asian J. Plant sci., 1(5): 565-566

Chourasia, A., Viradia, R.R., Ansar, H., Shubham, N.M.,(2015). Evaluation of different Gladiolus cultivars for, growth, flowering, spike yield and corm yield under Saurashtra region of Gujarat. International Quart Journal of Life Science.; 10(1):131-134

Chowdhuri, T.K., Rout, B., Sadhukhan, R., Mondal. T.,(2015). Performance evaluation of different varieties of China aster (Callistephus chinensis L. Ness.) In Sub tropical belt of West Bengal. International Journal of Pharmaceutical Science Invention, 5(8):15-18.

Dhane, A.V., Nimbalkar, C.A.,(2002). Growth and flowering performance of some Dahlia varieties. Journal of Maharashtra Agricultural Universities (India); 27(2):210-211.

Joshi, R.P., Mishra, Y.K., Solanki, S.S.,(1997). Performance of Dahlia cultivars under UP hill conditions.

Kanamadi, V.C., and Patil, A.A.,(1993) Performance of Chrysanthemum varieties in the transitional tract of Karnataka. South Indian Horticulture; 41(1):58-60

Kumar, L., Mahawer, L.N., Shukla, A.K., 
Kaushik, R.A., Upadhyay, B.,(2009). Performance of Dahlia (Dahalia variabilis) cultivars for vegetative, floral and relative economic parameters under sub humid southern pains and Aravalli hills of Udaipur. Indian Journal of Agriculture Science.; 79(10):816-820.

Mahawer, L.N., Kumar, L., Shukla, A.K., Bairwa, H.L.,(2010). Evaluation of dahlia cultivars under Aravalli hill conditions of Udaipur. Indian Journal of Horticulture.; 67(2):234-237.

Munikrishnappa, P.M., Patil, A.A., Patil, V.S., Patil, B.N., Channappagoudar, B.B., Alloli, T.B.,(2003). Studies on the growth and yield parameters of different genotypes of China aster (Callistephus chinensis Nees.). Karnataka Journal of Agricultural Science, 26(1):107-110

Negi, S.S., Rao. T.M., Ramchandran, N., Annual Report (1988). Indian Institute of Horticultural research, Hesaraghatta, Bangalore.

Pant, C.C., and Lal, S.D.,(1991). Genetic variability in Gladiolus. Progressive
Horticulture; 23:1-4.

Smith, A.W., (1971). In: Gardner's Dictonary of Plant Names. Cassell and Company Ltd, London, 1971, 390.

Suman, C.L., Wahi, S.D., Bhattacharjee, S.K.,(1991) Genetic analysis in Dahlia Variabilis. Definition of Agriculture and Science Digest (Karnal), 11(4):190-194.

Syamal, M.M., and Kumar, A.,(2002).Genetic variability and correlation studies on Dahlia. Journal of Ornamental Horticulture New Series; 5(1):40-42.

Vikas, H.M., Patil, V.S., Agasimani, A.D., Praveen kumar, D.A.,(2011). Studies on genetic variability in Dahlia. International Journal of Natural Sciences, 2(2):372-375.

Zosiamliana, J.H., Reddy, G.S.N., Rymbai, H., (2012). growth, flowering and yield characters of some cultivars of China aster (Callistephus chinensis Nees.). Journal of Natural Product and Plant Resources; 2(2):302-305..

\section{How to cite this article:}

Mounika, T. and Saravanan, S.S. 2019. Response of Different Varietal Evaluation of Dahlia (Dahlia variabilis L.) Under Prayagraj Agro-climatic Conditions. Int.J.Curr.Microbiol.App.Sci. 8(08): 2389-2397. doi: https://doi.org/10.20546/ijcmas.2019.808.278 